\title{
APPLICATION OF MAKE A MATCH MODEL TO IMPROVE GEOGRAPHY LEARNING OUTCOMES
}

\author{
Deasy Arisanty $(1 D$, Riyah 1 \\ Geography Education Department, Faculty of Teacher Training and Education, \\ Universitas Lambung Mangkurat (Indonesia) \\ deasyarisanty@ulm.ac.id,arriyah.amt@gmail.com
}

Received September 2018

Accepted December 2018

\section{Abstract}

This research was conducted to analyze the application of make a match learning model to improve the learning outcome of geography in class X of SMA PGRI 4 Banjarmasin with the material of geography principles. This research employed a quasi-experimental design method, quantitative approach and non-equivalent of pre-test and post-test control group design. The research included two groups namely the control and experimental groups. The number of the population was 67 students. All students in class $\mathrm{X}$ were used as the samples, where class $\mathrm{X} 1$ was as the experimental class and $\mathrm{X} 2$ was as the control class. Students in class X 1 and X-2 were 35 students and 32 students. The result of t-test showed that the value of post-test for experimental class using make a match learning model was 54.87 . The post-test result from the control class using the conventional model was 48.05. The post-test using the make a match had the higher learning outcome than the conventional model. The make a match learning model had increased the student learning outcome of geography.

Keywords - Learning model, Make a match, Geography learning outcomes.

\section{To cite this article:}

Arisanty, D. (2019). Application of make a match model to improve geography learning outcomes. Journal of Technology and Science Education, 9(1), 32-40. https://doi.org/10.3926/jotse.547

\section{Introduction}

Education plays a very important role in human life related to aspects of life. It can create qualified human beings such as on the learning process related to the material, objectives, activities, and evaluation of learning. It has been noted that education always has a very central role in improving the quality of human resources (Herman, 2007).

As a part of education, learning model is one of the important aspects. Learning model is a plan to design face-to-face learning in the classroom or in a tutorial setting and in shaping the learning materials. The use of learning model is an effort made by the teacher so that a student can be maximally in understanding the subject matter. The students will have the competence as the demands of the lesson material learned. Various learning models implemented have certain characteristics with all the advantages and disadvantages of each (Rubi, 2012). 
The learning model will be more lively if students also play an active role in it (Arisanty, Aristin \& Misna, 2018). Cooperative learning model, as one of the models, has many learning models that feature active interaction in the classroom for both students and teachers. Learning activity increases a student competence in a subject matter. Cooperative learning model solves the learning problems such as the student learning outcomes, student motivation and student creativity (Sunhaji, 2016). Cooperative learning models give the opportunity for the student to understand their capability (Ningsih, Soetjipto \& Sumarmi, 2017). Selection of cooperative learning model also determines the depth of learning material (Arisanty, Aristin \& Nasrullah, 2017). One of the cooperative learning models is the make a match, that students have an active role in the learning process in the class.

Make a match is an instructional technique of active learning including in the various make a match type revieving models (repetition models) relating to ways to recall what they have learned and test the current student's knowledge and skills with game techniques or game looking for the card pairs which is the answer or question while learning about a concept or topic in a fun atmosphere (Prihatmodjo, Darsono \& Sumadi, 2015). Make a match is a model to motivate students to find pairs of cards containing questions and answers. Make a match is kind of game where the students are divided into two groups i.e. group A and group B. Group A gets the topic cards and group B gets the description of topic cards. The students match about the topic cards and the description of topic cards (Zawil, 2016).

National examination score in SMA PGRI 4 Banjarmasin decreases every year. This school gets the lowest score of national examination for Senior High School in Banjarmasin area in academic year 2012/2013 and 2014/2015. The national examination score for geography subject also gets a low score. Based on observations in SMA PGRI 4 Banjarmasin, the low score of geography subject has been influenced by several factors, i.e. less interested in geography learning, less attention during geography lessons, students using handphone while studying, and less willing to listen during the learning process in the class. Therefore, the make a match learning model is needed to increase the student learning interest. The high of learning interest will increase the student learning outcome. Based the background, the objective of the research is to analyze the application of make a match learning model to improve the learning outcome of geography in class X of SMA PGRI 4 Banjarmasin with the material of geography principles.

\section{Methodology}

This research employed a quasi-experiment design and non-equivalent design. The design of quasiexperiment uses a control group that the experimental cannot control the outsides variables (Lestari \& Yudhanegara, 2015). The non-equivalent design used pre-test and post-test control group design. The researcher gave pretest for the two groups. The first group was given treatment and the second group was given the postest (Lestari \& Yudhanegara, 2015).

The population of this study was a number of 67 students. All students in class X were used as the samples. The students were divided into two classes, i.e. X 1 and X 2. A number of students in class X 1 consisted of 35 students. A number of students in class X 2 was 32 students.

Analysis of this data using the test data of learning outcomes i.e. the validity test, reliability test, the level of difficulty and different power. The validity test was used by the researcher to understand the validity of an instrument. The instrument in this research is a multiple choice test, that the number of questions is 15 questions. Reliability test was used to determine the level of the feasibility of the instrument, if the value is obtained high or reliable then the instrument can be trusted. Level of difficulty was used to find out the questions to be shared with students. The question was easy or difficult. Different power was used to find out whether on each item of learning outcomes that can differentiate students who have good ability and low ability. The result of instrument test (multiple choice tests) are presented in Table 1. 


\begin{tabular}{|c|c|c|c|c|c|c|c|c|c|}
\hline \multirow[b]{2}{*}{ No } & \multicolumn{2}{|c|}{ Validity } & \multicolumn{2}{|c|}{ Reliability } & \multicolumn{2}{|c|}{ Level of Difficulty } & \multicolumn{2}{|c|}{ Different Power } & \multirow[b]{2}{*}{ Description } \\
\hline & Value & Criteria & Value & Criteria & Value & Criteria & Value & Criteria & \\
\hline 1 & 0.592 & Middle & \multirow{15}{*}{1.041} & \multirow{15}{*}{ High } & 0.304 & Middle & 0.435 & Very good & Used \\
\hline 2 & 0.652 & High & & & 0.241 & Difficult & 0.345 & Good & Used \\
\hline 3 & 0.484 & Middle & & & 0.586 & Middle & 0.345 & Good & Used \\
\hline 4 & 0.609 & High & & & 0.478 & Middle & 0.435 & Very good & Used \\
\hline 5 & 0.475 & Middle & & & 0.793 & Easy & 0.345 & Good & Used \\
\hline 6 & 0.514 & Middle & & & 0.345 & Middle & 0.276 & Middle & Used \\
\hline 7 & 0.646 & High & & & 0.608 & Middle & 0.348 & Good & Used \\
\hline 8 & 0.665 & High & & & 0.695 & Middle & 0.435 & Very good & Used \\
\hline 9 & 0.835 & Very high & & & 0.739 & Easy & 0.435 & Very good & Used \\
\hline 10 & 0.665 & High & & & 0.695 & Middle & 0.435 & Very good & Used \\
\hline 11 & 0.935 & Very high & & & 0.652 & Middle & 0.522 & Very good & Used \\
\hline 12 & 0.830 & Very high & & & 0.608 & Middle & 0.522 & Very good & Used \\
\hline 13 & 0.494 & Middle & & & 0.565 & Middle & 0.348 & Good & Used \\
\hline 14 & 0.789 & High & & & 0.652 & Middle & 0.435 & Good & Used \\
\hline 15 & 0.577 & Middle & & & 0.448 & Middle & 0.414 & Very good & Used \\
\hline
\end{tabular}

Table 1. The results of instrument test of multiple choice tests

Data analysis uses $\mathrm{N}$-gain and t-test. N-Gain is used to understand the difference between the post-test score and the pre-test score and the improvement in the students' learning outcomes in both classes. T-test is used to find out after the normality test and homogeneity test. The formula for testing N-Gain (Equation 1) and t test (Equation 2) is as follows:

$$
<g>=\frac{T_{2}-T_{1}}{I_{2}-T_{1}}
$$

Note:

$<g>$ : gain test

$T_{1}$ : pre-test score

$T_{2}$ : post-test score

$I_{2}:$ ideal score $=100$

The normalized gain values were obtained for each student data, then data was calculated to get the average normalized gain value. The normalized gain averages are interpreted according to the criteria in Table 2.

\begin{tabular}{|c|c|c|}
\hline No & Category of N-gain & Category \\
\hline 1 & $(\mathrm{~g})<0,7$ & High \\
\hline 2 & $0,3<(\mathrm{g})>0,7$ & Middle \\
\hline 3 & $(\mathrm{~g})<0,3$ & Low \\
\hline
\end{tabular}

Table 2. Normalized gain criteria (Hake, 2002)

$$
t=\frac{X_{1}-X_{2}}{\sqrt{\frac{\left(n_{1}-1\right) S_{1}^{2}+\left(n_{2}-1\right) S_{2}^{2}+}{n_{1}+n_{2}-2}\left(\frac{1}{n_{1}}+\frac{1}{n_{2}}\right)}}
$$


Notes:

$t$ : The average equality test ( $t$ arithmetic)

$X_{1}$ : The first sample mean (which has a large value)

$X_{2}$ : The mean of the second sample (which has a small value)

$S_{1}^{2}$ : First sample variant

$S_{2}^{2}$ : Second sample variant

$n_{1}$ : Number of first individual samples

$n_{2}$ : Number of second individual samples

The hypothesis to be tested:

$H_{0}=$ no significant difference between the two data tested.

$H_{1}=$ a significant difference between the two data tested

Test criteria:

$H_{0}$ is accepted if $t_{\text {count }}<t_{\text {table }}$ and $H_{0}$ is rejected if $t_{\text {count }}>t_{\text {table }}$ with signification level $\alpha=5 \%$

\section{Results and Discussion}

\subsection{Characteristics of Students}

The total number of students in SMA PGRI 4 Banjarmasin for the academic year of 2015/2016 are 270 students. The number of students in academic year of 2016/2017 are 230 students. The number of students in academic year of 2017/2018 are 235 students. The list of students in academic year of 2017/2018 is presented in Table 3.

\begin{tabular}{|c|c|c|c|c|}
\hline \multirow[b]{2}{*}{ No } & \multirow[b]{2}{*}{ Class } & \multicolumn{2}{|c|}{ Number of students } & \multirow[b]{2}{*}{ Total } \\
\hline & & Male & Female & \\
\hline 1 & $\mathrm{X}$ & 35 & 32 & 67 \\
\hline 2 & $\mathrm{XI}$ & 40 & 29 & 69 \\
\hline 3 & XII & 42 & 57 & 99 \\
\hline \multicolumn{2}{|c|}{ Total } & 117 & 118 & 235 \\
\hline
\end{tabular}

Table 3. Number of students in the academic year of 2017/2018

\subsection{Pre-test and Post-test Results in Class X1 (Experiment Class)}

The results of quasi-experimental study in class X1 using make a match model as the experimental class is presented in Table 4.

The lowest pre-test score with the score of 13.2 is 4 students $(11.43 \%)$. The highest pre-test score with the score of 46.2 is 9 students $(25.71 \%)$. The lowest post-test score with the score of 13.2 is 1 student $(2.83 \%)$. The highest post-test score with the score of 79.2 is 3 students $(8.57 \%)$. The grade of students has improved after using by the make a match learning model. The student's grade has increased due to the make a match model makes more active and understand about the subject matter. The students will be easy to remember and to improve student learning outcomes compared with the conventional. 


\begin{tabular}{|c|c|c|c|c|c|c|}
\hline \multirow[b]{2}{*}{ No } & \multirow[b]{2}{*}{ Score } & \multicolumn{2}{|c|}{ Pre-test } & \multicolumn{2}{|c|}{ Post-test } & \multirow[b]{2}{*}{ Different } \\
\hline & & $\mathbf{F}$ & $\%$ & $\mathbf{F}$ & $\%$ & \\
\hline 1 & 6.6 & - & - & - & - & - \\
\hline 2 & 13.2 & 4 & 11.43 & 1 & 2.83 & 3 \\
\hline 3 & 19.8 & 4 & 11.43 & 1 & 2.83 & 3 \\
\hline 4 & 26.4 & 5 & 14.28 & - & - & 5 \\
\hline 5 & 33.0 & 7 & 20.00 & 3 & 8.57 & 4 \\
\hline 6 & 39.6 & 6 & 17.14 & 6 & 17.14 & 0 \\
\hline 7 & 46.2 & 9 & 25.71 & - & - & 9 \\
\hline 8 & 52.8 & - & - & 6 & 17.14 & 6 \\
\hline 9 & 59.4 & - & - & 2 & 5.71 & 2 \\
\hline 10 & 66.0 & - & - & 10 & 28.57 & 10 \\
\hline 11 & 72.6 & - & - & 3 & 8.57 & 3 \\
\hline 12 & 79.2 & - & - & 3 & 8.57 & 3 \\
\hline 13 & 85.8 & - & - & - & - & - \\
\hline 14 & 92.4 & - & - & - & - & - \\
\hline \multirow[t]{2}{*}{15} & 99.0 & - & - & - & - & - \\
\hline & Total & 35 & 100 & 35 & 100 & 48 \\
\hline
\end{tabular}

Table 4. Pre-test and post-test result of experimental class

\subsection{Pre-test and Post-test Results Class X2 (Control Class)}

The results of pre-test and post-test as a control class is presented in Table 5.

\begin{tabular}{|c|c|c|c|c|c|c|}
\hline \multirow[b]{2}{*}{ No } & \multirow[b]{2}{*}{ Score } & \multicolumn{2}{|c|}{ Pre-test } & \multicolumn{2}{|c|}{ Post-test } & \multirow[b]{2}{*}{ Different } \\
\hline & & $F$ & $\%$ & $F$ & $\%$ & \\
\hline 1 & 0 & 4 & 12.50 & - & - & 4 \\
\hline 2 & 6.6 & 8 & 25.00 & 1 & 3.12 & 7 \\
\hline 3 & 13.2 & 6 & 18.75 & 2 & 6.25 & 4 \\
\hline 4 & 19.8 & 9 & 28.12 & 3 & 9.37 & 6 \\
\hline 5 & 26.4 & 2 & 6.25 & 2 & 6.25 & 0 \\
\hline 6 & 33.0 & 1 & 3.12 & - & - & 1 \\
\hline 7 & 39.6 & 2 & 6.25 & 3 & 9.37 & 1 \\
\hline 8 & 46.2 & - & - & 5 & 15.62 & 5 \\
\hline 9 & 52.8 & - & - & 2 & 6.25 & 2 \\
\hline 10 & 59.4 & - & - & 5 & 15.62 & 5 \\
\hline 11 & 66.0 & - & - & 6 & 18.75 & 6 \\
\hline 12 & 72.6 & - & - & - & - & 0 \\
\hline 13 & 79.2 & - & - & 2 & 6.25 & 2 \\
\hline 14 & 85.8 & - & - & 1 & 3.12 & 1 \\
\hline 15 & 92.4 & - & - & - & - & 0 \\
\hline 16 & 99.0 & - & - & - & - & 0 \\
\hline & Total & 32 & 100 & 32 & 100 & 44 \\
\hline
\end{tabular}

Table 5. Pre-test value and post-test in class x2 (Control Class)

The lowest pre-test score with the score of 0 is 4 students $(12.50 \%)$. The highest pre-test score with the score of 39.6 is 2 students $(6.25 \%)$. The lowest post-test score with a value of 6.6 is 1 student $(3.12 \%)$. The highest post-test score with the value of 85.8 is 1 student $(3,12 \%)$. The lowest to highest range ranges 
from 6.6 to 85.8 . Conventional method in class X2 (control class) on the material of geography principles can improve the value of student learning outcomes.

\subsection{Average Score of Learning Outcomes Between Pre-test and Post-test}

The average value of pre-test and post-test of the experimental class and control class is presented in Table 6.

\begin{tabular}{|c|c|r|r|r|}
\hline & & & \multicolumn{2}{|c|}{ Average Score } \\
\cline { 4 - 5 } No. & Class & Number of Students & Pre-test & \multicolumn{1}{c|}{ Post-test } \\
\hline 1 & X1 (Experiment Class) & 35 & 32.81 & 54.87 \\
\hline 2 & X2 (Control Class) & 32 & 14.85 & 48.05 \\
\hline
\end{tabular}

Table 6 . The average score of learning outcome

The result of the average score of pre-test of both the experimental class and control class has a different average value, the average score of class X1 (experimental class) is 32.81 and the average score of X2 (control class) is 14.85 . The average post-test score for the experimental class is 54.87 . The average post-test score in control class is 48.05 . The difference score between experiment class score and control class score is 6.82. The experimental class has the higher post-test score than the control class. The use of make a match model can improve the geography learning outcomes better than the conventional model.

\subsection{The t-test}

The t-test is used to perform hypothesis testing on the difference of two average parameters. It aims to study the difference in the average of the criterion variables of the two groups or which can be classified into two groups (Kadir, 2015). The t-test in this study used non-parametric sample free samples, where this sample of its existence does not affect each other. The t-test result of post-test of experimental class (class X1) and control class (class X2) is presented in Table 7.

\begin{tabular}{|c|c|c|c|c|c|c|c|c|c|}
\hline \multirow{3}{*}{$\begin{array}{c}\text { Value } \\
\begin{array}{c}\text { Equal variances } \\
\text { assumed }\end{array}\end{array}$} & \multicolumn{2}{|c|}{$\begin{array}{l}\text { Levene's Test } \\
\text { for Equality of } \\
\text { Variances }\end{array}$} & \multicolumn{7}{|c|}{ t-test for Equality of Means } \\
\hline & $\mathbf{F}$ & Sig & $\mathbf{T}$ & Df & Sig.(2-tailed) & $\begin{array}{c}\text { Means } \\
\text { difference }\end{array}$ & $\begin{array}{l}\text { Std.Error } \\
\text { difference }\end{array}$ & $\begin{array}{r}95 \% \text { Co } \\
\text { Interva } \\
\text { Diffe }\end{array}$ & $\begin{array}{l}\text { idence } \\
\text { of the } \\
\text { nce }\end{array}$ \\
\hline & 1.390 & .243 & 1.465 & 65 & .148 & 6.818 & 4.653 & -2.474 & 16.110 \\
\hline $\begin{array}{c}\text { Equal variances } \\
\text { not assumed }\end{array}$ & & & 1.451 & 59.694 & .152 & 6.818 & 4.697 & -2.579 & 16.215 \\
\hline
\end{tabular}

Table 7. The t-test value

Form the t-test results, it can be concluded that the post-test score of students using the make a match model is higher and more consistent than the conventional one. The result of t-test in table 6 shows the variance of the population of both experiment class and control class is equal or homogeneous because the variance of homogeneous data will then be selected equal column of variances assumed.

The $\mathrm{t}$-test line for equality is obtained $\mathrm{t}=1.465, \mathrm{df}=65$ and sig. $(2$ tailed $)$ or $\mathrm{p}$-value $=0.148 / 2=0.074>0.05$ or $\mathrm{H}_{0}$ is rejected, $\mathrm{H}_{1}$ is accepted, there is a significant difference between the experimental class and the control class. The result of t-test as a whole is the post-test value of the students for the material of geography principles has improved both experimental and control classes, but the experimental class learning result has greater improvement the learning outcomes of students on the material principles of geography than the control class. 
The experimental class uses to make a match learning model, that the activities of learning model become more interest, more active and not quickly bored compared to conventional learning, that teacher is as the focus of learning. Make a match learning model makes the learning process is easier for students.

Learning activities use the make a match model will also foster a sense of excitement and the realization of cooperation among students dynamically. Geography learning in SMA PGRI 4 Banjarmasin is more dominant using conventional methods. Teachers teach and give the assignment or practice in the student workbook.

Learning activities can still be optimized by arranging learning activities using learning models, that can help achieve the learning objectives. The condition of class X in SMA PGRI 4 is not yet equipped with media projector so that the students are not interested in learning activity. The make a match learning model has been proven to improve students' geography learning outcomes. This model can be recommended for geography learning activities, especially on geographic principles.

Make a match learning model has advantages and disadvantages. The advantages of the make a match learning model by Kurniasih and Berlin (2016) are a) able to create an active and fun learning atmosphere; b) the lesson material more attention to the students; c) able to improve student learning outcomes; d) foster an atmosphere of fun in the learning process; e) realization of cooperation among students dynamically; f) bringing a unified atmosphere of mutual help to all students. Disadvantages of make a match learning model consist of a) deeply requires guidance from teachers to do activities; $b$ ) the need for time restrictions; c) preparation of adequate materials and tools; d) risk of raising noise in a class with a large number of students ( $<30$ students/class); e) may interfere with the peace of learning in his left-right class (Rahmawati \& Suprihatiningrum, 2014).

Prihatmodjo, et al. (2015) show that the make a match learning model can improve students learning outcomes characterized by an increase of geography learning outcomes. The result of the research shows that the average of student's learning result on post-test (after applied learning model of make a match) is 66.22, while student's score on pre-test (before an applied model of make a match) is 46.25 . This score proves the increase in student learning outcomes after the applied model of make a match learning. The same result from Istiqomah (2010), Hidayah, Sunarno and Indriayu (2016), Syaifullah (2016) that the make a match learning model can improve student learning outcomes. The other advantages using make a match are increasing the learning achievement, increasing the cognitive ability of students, increasing the social studies quality, improving the teacher skill and student activity, increasing the student independent learning (Mertadi, Pudjawan \& Raga, 2014; Febriana, 2011; Susanti, Nurkamto \& Suharno, 2014).

\section{Conclusion}

Make a match has increased the geography learning outcomes in the experiment class on the material of geography principles in SMA PGRI 4 Banjarmasin. The post-test learning outcome using make a match obtains 54.87, while the post-test learning outcome using the conventional method obtains 48.05 . The result of the post-test value of the students for the material of geography principles has improved both the experimental class and control class, but the experimental class has greater improvement in the learning outcomes of students than the control class.

\section{Declaration of Conflicting Interests}

The authors declared no potential conflicts of interest with respect to the research, authorship, and/or publication of this article.

\section{Funding}

The authors received the financial support for publication of this article from the Faculty of Teacher Training and Education, Universitas Lambung Mangkurat, Banjarmasin, Indonesia. 


\section{References}

Arisanty, D., Aristin, N.F., \& Misna, M. (2018). Application Of Student Teams-Achievement Divisions (Stad) On Material Of Land Degradation And Impact on Humans. 1st International Conference on Social Sciences Education (44-46). Banjarmasin: Atlantis Press. https://doi.org/10.2991/icsse-17.2018.11

Arisanty, D., Aristin, N.F., \& Nasrullah, M. (2017). Implementation Of Contextual Teaching and Learning (CTL) to Improve The Geography. 5th South East Asia Development Research (SEA-DR) International Conference (233-235). Banjarmasin: Atlantis Press.

Febriana, A. (2011). Application of Cooperative Learning Model Type Make a Match to Enhance Quality of Learning Social Studies in Elementary School Students in Grades V Kalibanteng Kidul 01 Semarang. Jurnal Kependidikan Dasar, 1(2).

Hake, R.R. (2002). Assessment of Student Learning in Introducing Science Courses. Duke University.

Herman, T. (2007). Pebelajaran Berbasis Masalah untuk. Meningkatkan Kemampuan Berfikir Matematis Tingkat Tinggi Siswa Sekolah Menengah Pertama (SMP). Bandung: Universitas Pendidikan Indonesia.

Hidayah, N.W., Sunarno, \& Indriayu, M. (2016). The Implementation of Cooperative Learning by Using Jigsaw and Make a Match Method to Improve the Activity and Learning Outcomes of Social Science. The 2 nd International Conference On Teacher Training and Education. Surakarta: Universitas Sebelas Maret.

Istiqomah, S. (2010). Penerapan Model Pembelajaran Tipe Kooperatif Make a Match (Mencari Pasangan) untuk Meningkatkan Motivasi dan Hasil Belajar Mata Pelajaran IPS Geografi pada Pokok Babasan Ketenagakerjaan pada Siswa Kelas VIII-B SMP Negeri 16 Surakarta. Surakarta: Universitas Sebelas Maret.

Kadir (2015). Statistika Terapan. Jakarta: Rajawali Press.

Kurniasih, I., \& Berlin, S. (2016). Ragam Pengembangan Model Pembelajaran untuk Peningkatan Profesionalisme Guru. Surabaya: Kata Pena.

Lestari, K.E., \& Yudhanegara, M.R. (2015). Penelitian Pendidikan Matematika. Bandung: PT Refika Aditama.

Mertadi, G., Pudjawan, I., \& Raga, I. (2014). Penerapan Model Make a Match Berbantuan Media Kartu Angka untuk Meningkatkan Perkembangan kognitif Anak di TK Buana Sutha Selemadeg. E Journal PG PAUD Universitas Pendidikan Ganesha, 2(1).

Ningsih, Soetjipto, B., \& Sumarmi (2017). Improving the Students' Acivity and Learning Outcomes on Social Sciences Subject Using Round Table and Rally Coach of Cooperative Learning Model. Education and Practice, 8(11).

Prihatmodjo, A., Darsono, \& Sumadi (2015). Pengaruh Model Make a Match terhadap Hasil Belajar Geografi. Studi Sosial Universitas Lampung.

Rahmawati, G., \& Suprihatiningrum, J. (2014). Pengaruh Model Pembelajaran Kooperatif Tipe Make a Match terhadap Nilai Kerjasama dan Hasil Belajar Kognitif Kimia Siswa Kelas X SMAN1 Bambanglipuro Bantul. Kannia, 4(10).

Rubi, A.P. (2012). Penerapan Model Berbasis Masalah (Problem Based Learning) untuk. Meningkatkan Prestasi Belajar Siswa pada Mata Diklat Praktik Dasar Intalasi Listrik (PDIL) di SMK Mubammadiyah 3 Yogyakarta. Yogyakarta: Universitas Negeri Yogyakarta.

Sunhaji (2016). Implementation of Cooperative Learning Strategy in Forming the Student about Thinking Skill of the Whole of State Islamic Senior High Schools in Purwokerto City Indonesia. International Journal of Education Research, 4(10). 
Susanti, E., Nurkamto, J., \& Suharno (2014). Pembelajaran Kooperatif Tipe Make a Match dan Pembelajaran Konvensional terhadap Hasil Belajar PKn ditinjau dari Kemandirian Belajar Siswa pada MTs N di Kabupaten Kudus. Teknologi Pendidikan dan Pembelajaran, 2(2), 257-272.

Syaifullah, M. (2016). Pembelajaran Kooperatif Tipe Make a Match dalam Meningkatkan Penguasaan Kosa Kata Bahasa Arab Santri TPA Al-Barokah Hadimulyo Timur Metro Pusat. At-Ta'dib, 11(2). https://doi.org/10.21111/at-tadib.v11i2.781

Zawil, R. (2016). Using Make a Match Tehnique to Teach Vocabulary. English Education Journal (EEJ), 7(3), 311-328.

\author{
Published by OmniaScience (www.omniascience.com) \\ Journal of Technology and Science Education, 2019 (www.jotse.org)
}

\title{
(c) (1) (\$)
}

Article's contents are provided on an Attribution-Non Commercial 4.0 Creative commons International License. Readers are allowed to copy, distribute and communicate article's contents, provided the author's and JOTSE journal's names are included. It must not be used for commercial purposes. To see the complete licence contents, please visit https://creativecommons.org/licenses/by-nc/4.0/. 